\title{
Induction of Differentiation in Acute Promyelocytic Leukemia Cells (HL-60) by the Verticillin Derivative Sch 52900
}

\author{
Gerhard Erkel ${ }^{\mathrm{a}, *}$, Alexandra Gehrt ${ }^{\mathrm{b}}$, Timm Anke $^{\mathrm{b}}$ and Olov Sterner ${ }^{\mathrm{c}}$ \\ a Institut für Biotechnologie und Wirkstoff-Forschung e. V., Erwin-Schrödinger-Str. 56, \\ D-67663 Kaiserslautern, Germany. Fax: (+49)-631-316-7212. E-mail: erkel@ibwf.de \\ b Lehrbereich Biotechnologie der Universität Kaiserslautern, Paul-Ehrlichstr. 23, \\ D-67663 Kaiserslautern, Germany \\ c Division of Organic Chemistry 2, Chemical Center, University of Lund, \\ S-22100 Lund, Sweden \\ * Author for correspondence and reprint requests \\ Z. Naturforsch. 57c, 759-767 (2002); received March 4/March 25, 2002 \\ Differentiation Induction, AP-1, p21 WAF
}

The HL-60 cell line, derived from a patient with acute promyelocytic leukemia, is a widely used model system to study the cellular and molecular events involved in differentiation of leukemic cells. In a screening for inducers of differentiation of HL-60 cells, cultures of Gliocladium strain 4-93 were found to produce Sch 52900, a previously isolated diketopiperazine (Chu et al,. J. Antibiotics 48, 1440-1445). Sch 52900 induced the differentation of 50-69\% of HL-60 cells at concentrations of $6.8-13.6 \mathrm{~nm}$ as measured by nitro-blue tetrazolium chloride (NBT) reduction which was followed by apoptosis as shown by DNA fragmentation. Our results demonstrate that growth arrest and the induction of differentiation by Sch 52900 is due to the induction of the cell cycle inhibitor p21 $\mathrm{WAF}$ and an inhibition of the extracellular signal-regulated kinase (ERK) signaling pathway which leads to the activation of the transcription factor AP-1.

\section{Introduction}

Tumor cells differ from their normal counterparts by the ability to evade the regulatory mechanisms of their environment and to propagate in an uncontrolled fashion. Among the phenotypic abnormalities in acute leukemia is the lack of granulocytes, macrophages and platelets caused by the inability of the neoplastic leukocytes to undergo terminal differentiation (Scott, 1997; Warrell et al., 1993; Lin et al., 1999). Recent approaches in the treatment of leukemias include the use of differentiation-inducing agents like alltrans-retinoic acid (ATRA), 1 $\alpha, 25$-dihydroxyvitamin $\mathrm{D}_{3}\left(1 \alpha, 25-(\mathrm{OH})_{2} \mathrm{D}_{3}\right)$ and low dose arabinosylcytosine (Hozumi, 1998). The HL-60 cell line, derived from a patient with acute promyelocytic leukemia, is a widely used model system to study the cellular and molecular events involved in differentiation of leukemic cells. HL-60 cells can be induced to differentiate in vitro from an immature form into different cell types of the myelomonocytic lineage by various compounds including ATRA, 9-cis-retinoic acid (9-cis-RA) (into granulocytes $), 1 \alpha, 25-(\mathrm{OH})_{2} \mathrm{D}_{3}$ or 12-O-tetradecanoyl- phorbol-13-acetate (TPA) (into monocytes/macrophages) (Hozumi, 1998; Collins, 1987). Differentiation may be followed by apoptosis, a process of active DNA fragmentation (McGahon et al., 1995). The induction of differentiation and apoptosis is regulated by a network of signal transduction pathways and transcription factors, which are possible targets for a rational tumor therapy (Thompson, 1995; Kinloch et al., 1999). The search for new pharmacologically active drugs from natural sources like bacteria, plants and fungi has led to the discovery of many clinically useful drugs and approximately $60 \%$ of the antitumor agents which are clinically used or in the late stages of development are from natural origin (Shu, 1998). In the course of a screening of fungal cultures for differentiation-inducing metabolites, cultures of the imperfect fungus Gliocladium, strain 4-93, were found to produce a strong inducer of differentiation and apoptosis of HL-60 cells. The isolation and structural elucidation revealed the identity of our compound with Sch 52900, a previously isolated diketopiperazine from a Gliocladium species (Chu et al., 1995). Beside the inhibition of a c-fos dependent reporter gene, no biological activ- 
ities of the compound have been reported. In this paper we show that the induction of differentiation and apoptosis of HL-60 cells caused by Sch 52900 is due to an induction of the cell cycle inhibitor protein p21 and an interference with the AP-1 signaling pathway.

\section{Materials and Methods}

\section{Producing organism}

The Gliocladium strain 4-93 (anamorphic Spherostibella; Hypocreacea, Ascomycetes) was isolated from rotting plant material. The specimen showed the characteristics of the genus Gliocladium but the species could not be determined (Domsch et al., 1993). The strain was kindly provided by $\mathrm{H}$. Anke and is deposited in the culture collection of the LB Biotechnologie, Universität Kaiserslautern.

\section{Fermentation and isolation of Sch 52900}

For maintenance on agar slants the strain was kept on YMG medium (malt extract, 1\%, glucose, $0.4 \%$, yeast extract, $0.4 \%, \mathrm{pH}, 5.5)$. For submerged cultivation, strain 4-93 was grown in corn meal medium (corn meal, 1\%; glucose, $1 \% ; \mathrm{KH}_{2} \mathrm{PO}_{4}$, $0.15 \% ; \mathrm{KCl}, 0.05 \% ; \mathrm{NaNO}_{3}, 0.05 \% ; \mathrm{MgSO}_{4} \times$ $\left.7 \mathrm{H}_{2} \mathrm{O}, 0.05 \%, \mathrm{pH}, 5.5\right)$. A well grown seed culture of Gliocladium strain 4-93 (200 ml YMG medium) was used to inoculate a Biolafitte C-6 fermenter containing 201 of corn meal medium (31 air/min) and agitation $(120 \mathrm{rpm})$ at $22{ }^{\circ} \mathrm{C}$. The production of Sch 52900 was followed by measuring the induction of differentiation of HL-60 cells by various concentrations of a crude extract. After 10 days of fermentation the mycelia were separated from the culture broth and extracted twice with a total amount of 8 liters methanol-acetone $(1: 1 \mathrm{v} / \mathrm{v})$. The organic solvents were evaporated and the remaining aqueous residue was extracted with ethyl acetate, dried with $\mathrm{Na}_{2} \mathrm{SO}_{4}$ and concentrated in vacuo $\left(40^{\circ} \mathrm{C}\right)$. The culture filtrate was applied onto Mitsubishi DIAION HP 21 resin, washed with water and the active compound was eluted with acetone. The eluate was concentrated and the remaining aqueous residue extracted with ethyl acetate. The crude mycelial $(1.3 \mathrm{~g})$ and culture filtrate extracts $(0.95 \mathrm{~g})$ were separated by subsequent chromatography on silica gel
(Merck 60, eluent: cyclohexane: EtOAc, 6:4 v/v) and Sephadex LH20 (eluent: $\mathrm{MeOH}$ ). The enriched mycelial $(38 \mathrm{mg})$ and culture filtrate products $(23 \mathrm{mg}$ ) were further purified by preparative HPLC (Merck LiChrospher WP 300 RP 18, $12 \mu \mathrm{M}$; column $250 \times 25 \mathrm{~mm}$; flow $5 \mathrm{ml} / \mathrm{min} ; \mathrm{H}_{2} \mathrm{O}: \mathrm{MeOH}$, $8: 2 \mathrm{v} / \mathrm{v}$ ) to yield $3.4 \mathrm{mg}$ pure Sch 52900 . The structure elucidation was done by spectroscopic methods.

\section{Biological assays}

The antimicrobial spectra, cytotoxicity and macromolecular syntheses in whole HL-60 cells (ATCC CCL 240) were measured as described previously (Anke et al., 1989). Cell viability was measured by the XTT test (Roche Diagnostics) and Giemsa staining. HeLa S3 (ATCC CCL 2.2), COS-7 (ATCC CRL 1651), HepG2 (ATCC HB 8065), BHK 21 (ATCC CRL 8544) and Colo 320 cells (DSMZ ACC 144) were grown in Dulbecco's modified eagle medium (D-MEM). HL-60 (ATCC CCL 240), U-937 (ATCC CRL 1593), L1210 (ATCC CCL 219) and Jurkat cells (ATCC TIB 152) cells were grown in RPMI-1640 supplemented with $10 \%$ fetal calf serum (FCS) and $65 \mu \mathrm{g} / \mathrm{ml}$ benzylpenicillin and $100 \mu \mathrm{g} / \mathrm{ml}$ streptomycin sulfate in a humidified atmosphere containing $5 \%$ of $\mathrm{CO}_{2}$ at $37^{\circ} \mathrm{C}$.

The induction of morphological and physiological differentiation of HL-60 cells was assayed as described previously (Erkel et al., 1996a). The cells were grown for 4 days with or without the compounds to be tested. Differentiated cells reduced the water-soluble nitro-blue tetrazolium chloride (NBT) to blue-black cell-associated nitro-blue diformazan deposits. For quantification the percentage of stained cells was determined. The induction of morphological and physiological differentiation of U-937 cells was assayed as described for HL-60 cells with the following modifications: The concentration of phorbolester (TPA) in the NBT dye solution was increased to $10 \mathrm{mg} / \mathrm{ml}$ and the incubation time with the dye solution was increased to 60-120 minutes. Apoptosis was measured as described by Nagy et al. (1995), with slight modifications: HL-60 cells $\left(5 \times 10^{5} / \mathrm{ml}\right.$ in a 24 -well tissue culture plate) were incubated with different concentrations of the test compound for 16 or 96 hours and collected by centrifugation at $200 \times g$ 
for $10 \mathrm{~min}$ at $4{ }^{\circ} \mathrm{C}$. After washing with phosphate buffered saline (PBS) the cells were lysed by the addition of $200 \mu \mathrm{l}$ of $20 \mathrm{~mm}$ tris(hydroxymethyl)aminomethane-hydrochloride (Tris- $\mathrm{HCl}, \mathrm{pH} 7.4$ ), $0.4 \mathrm{~mm}$ EDTA, $0.4 \%$ Triton X-100, transferred to a microcentrifuge tube, and centrifugated at $4000 \times g$ for 10 minutes at $4{ }^{\circ} \mathrm{C}$. The supernatants were collected, adjusted to $0.5 \mathrm{M} \mathrm{NaCl}$ (final concentration), and the DNA was precipitated by addition of $250 \mu \mathrm{l}$ isopropanol. The DNA was collected by centrifugation at $15,000 \times g$ for $30 \mathrm{~min}-$ utes, washed once with $70 \%$ ethanol and the samples were separated by electrophoresis on a $1.5 \%$ agarose gel.

\section{Reporter gene assays}

The reporter plasmids pGE3-NF1 and pGE2AP1 have been described recently (Erkel et al., 1996b). Both plasmids carry the reporter gene secreted alkaline phosphatase (SEAP) under the control of a thymidine kinase promoter and $5 \times \mathrm{NF}-x \mathrm{~B}$ or an enhancerless SV40 promoter and $3 \times$ AP-1 binding sites. The reporter plasmid pGE3-NFAT contains the reporter gene SEAP under the control of the thymidine kinase promoter and five copies of the distal NF-AT/AP-1 binding site from the human IL-2 promoter (Matilla et al., 1990). For expression of the constitutive active MEK 1, the vector pFC-MEK1 was used, which expresses a mutant protein containing a S218E/S222E double mutation and a deletion from amino acid 32-51 (Stratagene). Transfection of HeLa S3 and COS-7 cells and determination of the activity of the expressed SEAP was performed as described previously (Erkel et al., 1996a). The transfection of Jurkat, HL-60 and U937 cells was performed by electroporating (BioRad, Gene Pulser) $6 \times 10^{7}$ cells $/ \mathrm{ml}$ in $0.2 \mathrm{ml}$ HEBS buffer (10 mм 2-[4-(2-hydroxyethyl)-1-piperazinyl]-ethanesulfonic acid (HEPES, pH 7.05), $68.5 \mathrm{~mm} \mathrm{NaCl}, 2.5 \mathrm{~mm} \mathrm{KCl}, 0.35 \mathrm{~mm} \mathrm{Na} \mathrm{HPO}_{4}$, $3 \mathrm{~mm}$ dextrose) together with $30 \mu \mathrm{g}$ of the indicated reporter plasmids at $500 \mathrm{~V} / \mathrm{cm}$. After electroporation the cells were seeded at $1 \times 10^{6}$ cells/ml OPTI-MEM medium (GIBCO) containing $10 \%$ FCS in a 24 well plate with and without test compounds and SEAP expression was induced as indicated. The activity of the SEAP in the culture medium was determined 24 hours after transfection using the Phospha-Light chemoluminiscent reporter gene assay (TROPIX, MA) according to the manufacturer's instructions with a liquid scintillation counter.

\section{Electrophoretic mobility shift assays (EMSAs) and Western blots}

HL-60 cells were starved for $16 \mathrm{~h}$ in RPMI medium with $0.5 \% \mathrm{FCS}$, treated for the indicated times with the test compounds and induced with various concentrations of TPA. Total cell extracts were prepared using a high-salt detergent buffer and tested for binding to the AP-1 binding sequence as described recently (Pahl and Baeuerle., 1995). For western blotting cell extracts $(50 \mu \mathrm{g})$ were analyzed by SDS-polyacrylamide gel (12\%) electrophoresis, transferred onto a nitrocellulose membrane, probed with an anti p21-antibody (Dianova) and afterwards with a goat anti-mouse antibody conjugated to horseradish peroxidase. Immunoreactive proteins were detected by enhanced chemiluminescence (ECL System, Amersham).

\section{Results}

Sch 52900 (Fig. 1) has been detected during fermentation and isolation by measuring the induction of differentiation of HL-60 cells by various concentrations of a crude extract as described in the experimental section.

Sch 52900 induced the differentation of $50-69 \%$ of HL-60 cells at concentrations of 6.8-13.6 nM as measured by NBT reduction (Table I). For comparison, DMSO and TPA were used as standards. $1.5 \%$ DMSO induced $70-80 \%$ of HL-60 cells to differentiate and treatment with TPA (1.6 nM) resulted in $60-70 \%$ of HL-60 to be differentiated.

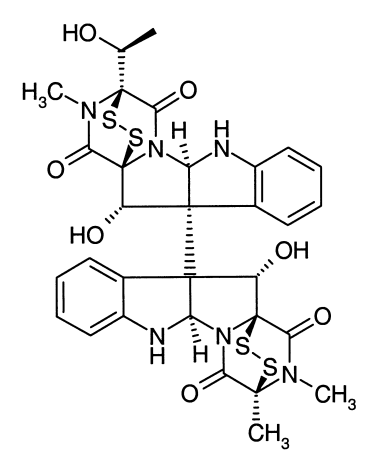

Fig. 1. Structure of Sch 52900. 
Table I. Differentiation of HL-60 cells after 96 hours of incubation.

\begin{tabular}{llll}
\hline Compound & $\begin{array}{l}\text { Concen- } \\
\text { tration } \\
{[\mathrm{nm}]}\end{array}$ & $\begin{array}{l}\text { Differen- } \\
\text { tiated cells } \\
{[\%]}\end{array}$ & $\begin{array}{l}\text { Growth } \\
{[\% \text { of }} \\
\text { control] }\end{array}$ \\
\hline $\begin{array}{l}\text { Control } \\
\text { DMSO }\end{array}$ & - & $4-8$ & 100 \\
$\begin{array}{l}12-O \text {-tetradecanoyl- } \\
\text { phorbol-13-acetate }\end{array}$ & 1.6 & $60-70$ & 45 \\
$\begin{array}{l}\text { Sch 52900 } \\
\text { [ }\end{array}$ & $6.8-13.6$ & $50-60$ & 47 \\
\hline
\end{tabular}

In the controls without additions $4-8 \%$ of HL-60 cells differentiated spontaneously. At the same concentration of the compound (6.8-13.6 nM) $40 \%$ of U-937 cells differentiated (Table II). Retinoic acid, used as positive control, induced $30-40 \%$ of the cells to differentiate. Controls without induction contained $1-2 \%$ spontaneously differentiated U-937 cells. In addition Sch 52900 inhibited the growth of HL-60 and U937 cells at concentrations starting from $13.6 \mathrm{~nm}$. Cytotoxic properties of the compound were evaluated against various cultured neoplastic cell lines. As shown in Table III, cytotoxic activities against most tested cell lines could be observed with $\mathrm{IC}_{90^{-}}$

Table II. Differentiation of U-937 cells after 96 hours of incubation.

\begin{tabular}{llll}
\hline Compound & $\begin{array}{l}\text { Concen- } \\
\text { tration } \\
{[\mathrm{nm}]}\end{array}$ & $\begin{array}{l}\text { Differen- } \\
\text { tiated cells } \\
{[\%]}\end{array}$ & $\begin{array}{l}\text { Growth } \\
{[\% \text { of }} \\
\text { control] }\end{array}$ \\
\hline $\begin{array}{l}\text { Negative control } \\
\text { Retinoic acid }\end{array}$ & - & $2-3$ & 100 \\
$\begin{array}{c}\text { 12-O-tetradecanoyl- } \\
\text { phorbol-13-acetate }\end{array}$ & 1.6 & $30-40$ & 48 \\
\begin{tabular}{l} 
Sch 52900 \\
\hline
\end{tabular} & $6.8-13.6$ & $40-70$ & 51 \\
\hline
\end{tabular}

Table III. Cytotoxic activity of Sch 52900 against various tumor cell lines in vitro.

\begin{tabular}{lc}
\hline Cell line & $\mathrm{IC}_{90}[\mathrm{~nm}]$ \\
\hline HL-60 & 34 \\
U-937 & 34 \\
L1210 & 34 \\
Jurkat & 34 \\
BHK 21 & 68 \\
Colo 320 & 680 \\
COS-7 & 68 \\
HeLa S3 & 68 \\
HepG2 & 1360 \\
\hline
\end{tabular}

values starting from $25 \mathrm{ng} / \mathrm{ml}$ (34 nM) during a $48 \mathrm{~h}$ incubation period. The $\mathrm{IC}_{90}$-values against $\mathrm{HepG} 2$ and Colo 320 cells were approximately 20-40 fold higher.

Microscopic examination of Sch 52900A treated HL-60 cells showed a cell shrinkage and micronuclear bodies which are characteristic for the induction of apoptosis. We therefore investigated the DNA fragmentation upon treatment of HL-60 cells with Sch 52900 by agarose gel electrophoresis. As shown in Fig. 2, treatment of the cells with $34 \mathrm{~nm}$ Sch 52900 resulted in a complete DNA fragmentation within $16 \mathrm{~h}$, which was comparable to $0.57 \mu \mathrm{M}$ camptothecin as positive control. Treatment of the cells with $13.6 \mathrm{~nm}$ Sch 52900 for $96 \mathrm{~h}$ showed a similar DNA fragmentation (data not shown).

The cell cycle inhibitor p21 (WAF) has been implicated in mediating growth arrest by various conditions including terminal differentiation. Recently it has been shown that treatment of HL-60 cells with TPA resulted in the induction of the $\mathrm{p} 21^{\mathrm{WAF}}$ protein and an increased expression of the cyclin/cdk inhibitor p27 by a MAP-Kinase dependent mechanism (Das et al., 2000). To determine whether the induction of HL-60 cell differen-

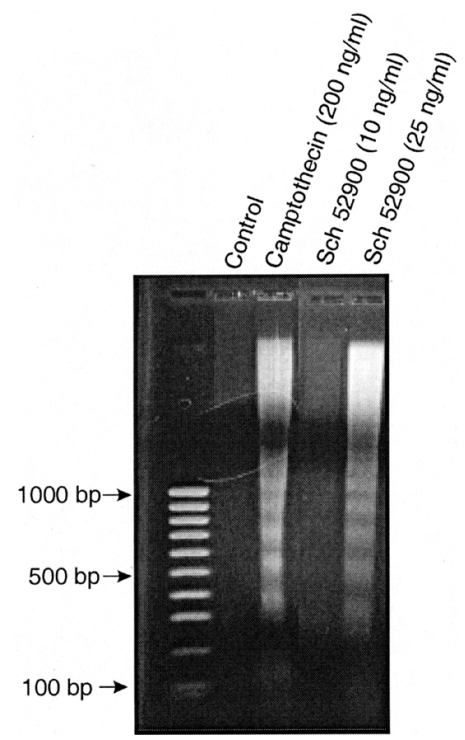

Fig. 2. Induction of apoptosis by Sch 52900. HL-60 cells were treated with or without test compounds for $16 \mathrm{~h}$. Subsequently DNA was extracted and analyzed by agarose gel electrophoresis as described in Materials and Methods. Molecular size markers were run on the left lane. 
tiation is due to an increase in the expression of the $\mathrm{p} 21^{\mathrm{WAF}}$ protein, HL-60 cells were treated with Sch 52900 or TPA for the indicated times and total cell extracts were immunoblotted with a p21 antibody. As shown in Fig. 3, exponentially growing HL-60 cells express no detectable amount of p21 WAF. Treatment of HL-60 cells with $5 \mathrm{ng} / \mathrm{ml}$ TPA resulted in a time-dependent induction of p21 expression. An induction of p21 expression was also detected after $12 \mathrm{~h}$ of Sch 52900 treatment, which was further increased after $24 \mathrm{~h}$ of incubation. This correlates well with the time when HL-60 cells undergo apoptosis as shown by DNA fragmentation.

The involvement of the ERK1/ERK2 kinase, the c-jun $\mathrm{N}$ terminal kinase and p38 MAP kinase pathways have been implicated in the induction of differentiation of HL-60 cells by retinoic acid and TPA (Meighan-Mantha et al., 1997; Wang and Studzinski, 2001). The common endpoint of these pathways is the induction of the transcription factor AP-1. We therefore investigated the influence of Sch 52900 on an AP-1 transcriptional reporter. Transfection of HL-60 or U 937 cells with an AP-1 specific reporter construct and induction with $25 \mathrm{ng} / \mathrm{ml}$ TPA resulted in a 20 to 40 fold increase in SEAP expression compared to the uninduced control (Fig. 4A). Low concentrations $(6.8 \mathrm{nM}, 5 \mathrm{ng} / \mathrm{ml})$ of Sch 52900 actually potentiated the stimulation of AP-1 activity in HL-60 cells whereas higher concentrations $(15 \mathrm{ng} / \mathrm{ml})$ inhib-

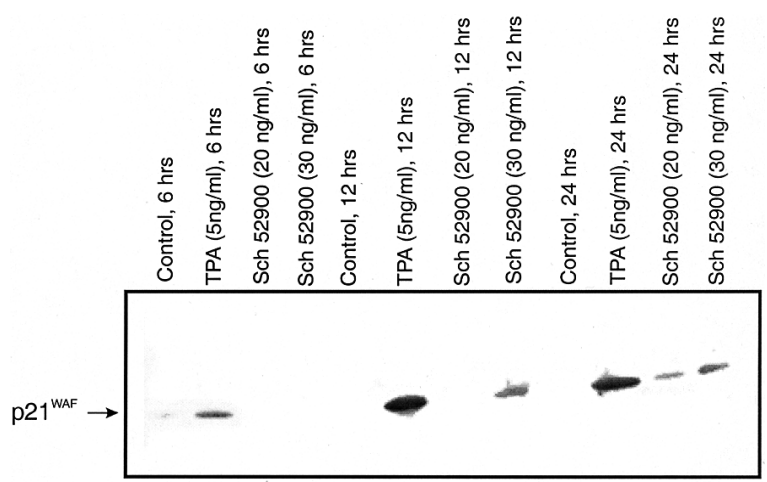

Fig. 3. Sch 52900 induced p21 WAF expression in HL-60 cells. HL-60 cells were treated for the indicated times with TPA or Sch 52900 and cell lysates were analyzed by Western blotting with an anti-p21 WAF antibody. No immunoactive bands other than $\mathrm{p} 21^{\mathrm{WAF}}$ were observed. The ascending bands to the right of the blot were caused by edge effects during the running of the gel.
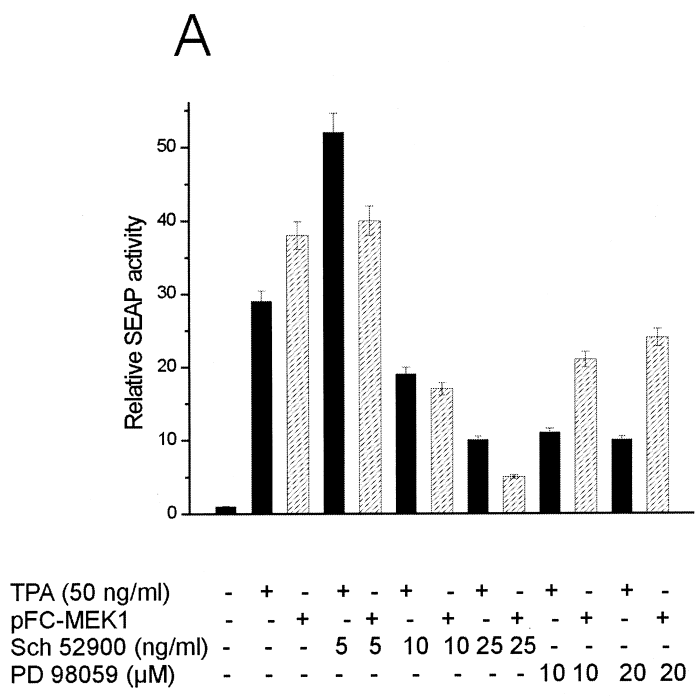

B

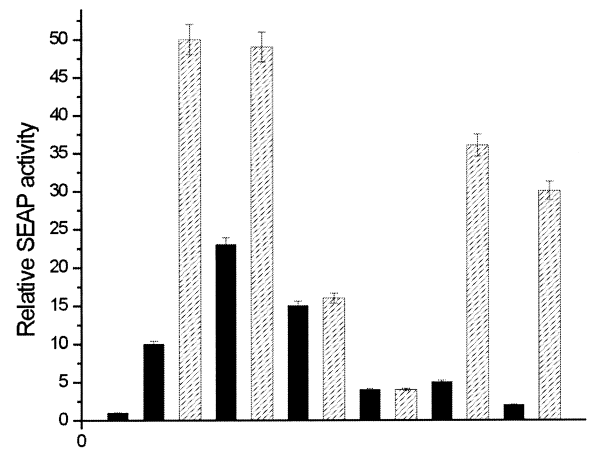

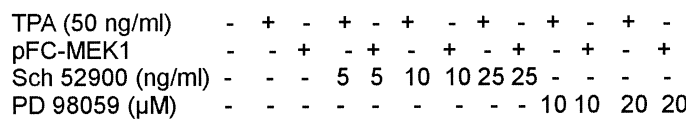

Fig. 4. Effect of Sch 52900 on AP-1 dependent reporter gene expression in HL-60 and HeLa S3 cells. (A): HL-60 cells were transfected either with an AP-1 dependent reporter gene plasmid (pGE2-AP1) and stimulated for $48 \mathrm{~h}$ with $50 \mathrm{ng} / \mathrm{ml}$ TPA with or without test compounds or cotransfected with a expression plasmid for a constitutive active MEK-1 mutant ( $\mathrm{pFC}-\mathrm{MEK} 1$ ). (B): HeLa S3 cells were transfected either with a AP-1 dependent reporter gene plasmid (pGE2-AP1) and stimulated for $48 \mathrm{~h}$ with $50 \mathrm{ng} / \mathrm{ml}$ TPA with or without test compounds or cotransfected with a expression plasmid for a constitutive active MEK-1 mutant. The expression of the reporter gene SEAP was determined as described in Materials and Methods. SEAP activity was calculated relative to the uninduced control. 
ited the AP-1 activity. In U-937 cells a concentration dependent inhibition of TPA induced AP-1 activity by Sch 52900 could be observed. Sch 52900 alone failed to induce AP-1 dependent reporter gene expression in either HL-60 or U-937 cells. In order to further characterize the influence of Sch 52900 on the AP-1 dependent signaling HL-60 and HeLa cells were transiently transfected with a constitutive active MEK-1 variant (caMEK-1). As shown in Fig. 4A, overexpression of caMEK-1in HL-60 cells caused a 38-fold increase in AP-1 dependent SEAP expression. These effects were suppressed by Sch 52900 in a concentration dependent manner. Transfection of HeLa S3 cells with the caMEK-1 expression plasmid resulted in a 50-fold increase in reporter gene activity (Fig. 4B). In HeLa S3 cells Sch 52900 inhibited AP-1 activity in the presence of coexpressed caMEK-1 to the same extend as in HL-60 cells ( $\left.\mathrm{IC}_{50}: 10 \mathrm{ng} / \mathrm{ml}, 13.6 \mathrm{~nm}\right)$. These data indicate a target for Sch 52900 downstream of MEK-1 in the AP-1 pathway. CaMEK1 mediated induction of AP-1 activity was only slightly affected by the synthetic compound 2-(2amino-3'-methoxy)-flavone (PD98059), which is in accordance with the proposed mode of action as an inhibitor of MEK-1 activation by upstream protein kinases such as Raf (Alessi et al., 1995).

In order to determine the effect of Sch 52900 on activation of the AP-1 transcription factor complex, EMSA's of whole cell extracts with a high affinity AP-1 binding site have been performed. No detectable AP-1 DNA binding activity was found in unstimulated HL-60 cells (Fig. 5). Stimulation of HL-60 cells with TPA, an activator of

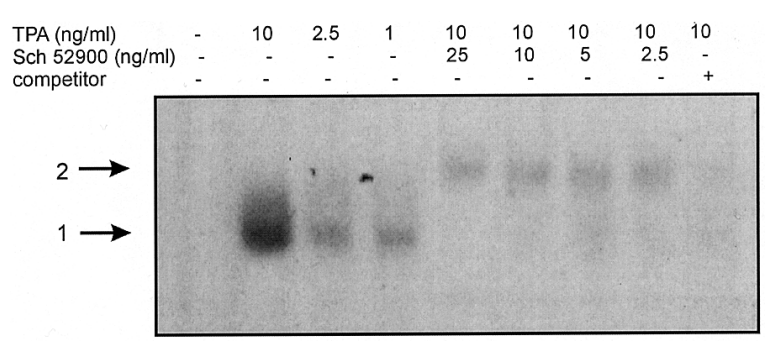

Fig. 5. Effect of Sch 52900 on AP-1 activation in HL-60 cells. HL-60 cells were with TPA alone or in combination with Sch 52900 for $16 \mathrm{~h}$. Total cell extracts of equal amounts of protein were then analyzed by EMSA for DNA binding activity using a ${ }^{32}$ P-labelled oligonucleotide with a high affinity AP-1 binding site. Competitor: 100 -fold molar excess of unlabelled probe. The inducible AP-1 complexes are indicated by arrows. protein kinase $\mathrm{C}$, for $16 \mathrm{~h}$ resulted in a concentration-dependent induction of AP-1 binding activity (band 1), which disappeared after addition of a 10 fold excess of unlabelled AP-1 probe. Incubation of HL-60 cells with $10 \mathrm{ng} / \mathrm{ml}$ TPA and different concentrations of Sch 52900 lead to a complete loss of the faster migrating AP-1 binding activity starting from $2.5 \mathrm{ng} / \mathrm{ml}(3.4 \mathrm{~nm})$ of the compound. In addition the appearance of a second upper band (2) could be observed which may be due to an alteration in the composition of the AP-1 transcription factor complex (Angel and Karin, 1991).

The related diketopiperazine gliotoxin has been described to inhibit the activation of the transcription factor NF- $x \mathrm{~B}$ by blocking the catalytic activities of the $20 \mathrm{~S}$ proteasome and preventing the degradation of the phosphorylated form of the inhibitor protein IxB (Pahl et al., 1996; Kroll et al., 1999). It has been suggested that the immunosuppressive activities of gliotoxin are at least partially due to the interference with the NF- $x \mathrm{~B}$ dependent pathway. Therefore we investigated the influence of Sch 52900 on the expression of a NF- $x$ B dependent SEAP reporter gene construct in transiently transfected HeLa S3 cells after stimulation with TPA. No inhibition of the NF- $x \mathrm{~B}$ mediated expression of the reporter gene could be observed at concentrations of up to $10 \mathrm{ng} / \mathrm{ml}$ of the compound. The transcription factors AP-1, NF- $x$ B and NF-AT have been shown to be essential for the inducible interleukin-2 (IL-2) expression in activated T-cells (Rooney et al., 1995). Treatment of Jurkat T-cells with ionomycin, which elevates intracellular levels of calcium and TPA, which activates protein kinase $\mathrm{C}$, can mimic the activation of T-cells by the T-cell receptor (Flanagan and Crabtree, 1992). In order to determine the effect of Sch 52900 on T-cell activation, Jurkat cells were transiently transfected with a reporter plasmid expressing the reporter gene SEAP under the control of five copies of the distal NF-AT/AP-1 binding site from the human IL-2 promoter. Sch 52900 inhibited the TPA/ionomycin induced NF-AT mediated SEAP expression with an $\mathrm{IC}_{50}$-value of $1 \mathrm{ng} / \mathrm{ml}(1.4 \mathrm{~nm})$ In addition $2.5 \mathrm{ng} / \mathrm{ml} \mathrm{Sch} 52900$ inhibited the inducible IL-2 synthesis in TPA/ionomycin stimulated Jurkat cells to $80 \%$ (Fig. 6A,B). Higher concentrations completely blocked the IL-2 synthesis in Jurkat cells. Sch 52900 also inhib- 
A

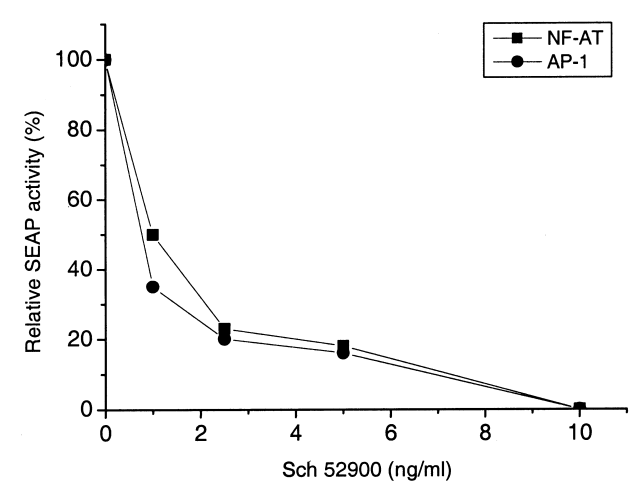

B

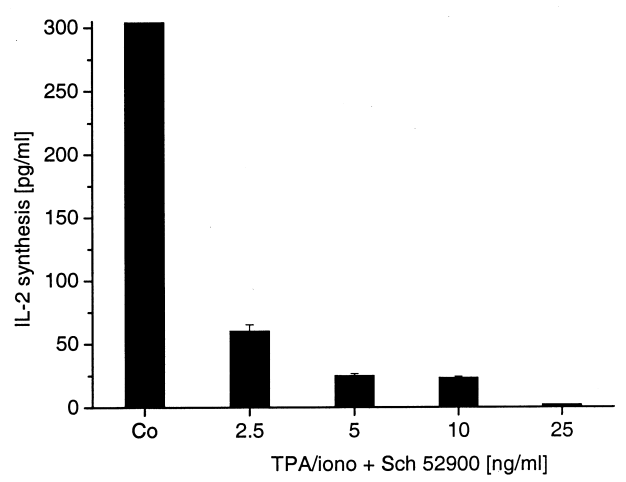

Fig. 6. Effect of Sch 52900 on NF-AT/AP-1, AP-1 dependent SEAP reporter gene expression and IL-2 synthesis in Jurkat cells. (A) Jurkat cells were transfected with a $5 \times$ NF-AT/AP-1 or a $3 \times$ AP-1 driven SEAP reporter gene plasmid and stimulated with $32 \mathrm{~nm} \mathrm{TPA} / 2.5 \mu \mathrm{M}$ ionomycin or $50 \mathrm{ng} / \mathrm{ml}$ TPA for $24 \mathrm{~h}$ with or without Sch 52900 . Contol (100\%): stimulation only. The expression of the reporter gene SEAP was determined as described in Materials and Methods. (B): Jurkat cells were pretreated for $1 \mathrm{hr}$ with or without Sch 52900 and stimulated with $32 \mathrm{~nm}$ $\mathrm{TPA} / 2.5 \mu \mathrm{M}$ ionomycin or $50 \mathrm{ng} / \mathrm{ml} \mathrm{TPA}$ for additional $24 \mathrm{~h}$. Interleukin-2 concentrations from cell supernatants were determined by ELISA.

ited the AP-1 driven expression of the SEAP reporter gene in TPA stimulated Jurkat cells with an $\mathrm{IC}_{50}$-value of $1 \mathrm{ng} / \mathrm{ml}(1.4 \mathrm{~nm})$.

\section{Discussion}

In a screening of fungal extracts for differentiation inducing metabolites, we identified the verticillin derivative Sch 52900 as a strong inducer of differentiation of HL-60 and U937 cells at concentrations starting from $6.8 \mathrm{~nm}(5 \mathrm{ng} / \mathrm{ml})$. In addition, an inhibition of proliferation and the induction of DNA fragmentation, a hallmark of apoptosis, was observed after treatment of HL-60 cells. Our data provide evidence that the inhibition of proliferation and the induction of differentiation of HL-60 cells by Sch 52900 is due to an induction of the cell cycle inhibitor $\mathrm{p} 21^{\mathrm{WAF}}$. Since HL-60 cells have a null-p53 phenotype our results demonstrate that p21 induction during terminal differentiation occurs independently of p53. Several other differentiation inducing agents like TPA, retinoic acid, $1 \alpha, 25-(\mathrm{OH})_{2} \mathrm{D}_{3}$, okadaic acid and IFN- $\gamma$ have been shown to result in an induction of the $\mathrm{p} 21^{\mathrm{WAF}}$ protein which correlates with growth arrest and differentation (Jiang et al., 1994; Zhang et al., 1995).

All three MAPK cascades, the ERK, JNK and p38 MAPK pathways have been implicated in differentiation of mammalian cells. Recent studies have demonstrated that the involvement of MAPK cascades in differentiation is cell specific and that there are profound differences between the mechanisms of TPA, retinoic acid or $1 \alpha, 25$ $(\mathrm{OH})_{2} \mathrm{D}_{3}$ induced differentiation (Wang and Studzinski, 2001). The common endpoint of the MAPK cascades is the activation of the transcription factor AP-1 composed of different members of the c-Jun and c-Fos families which form a variety of homo- and heterodimers and bind to a common binding site in the promoter of genes responsible for proliferation, differentiation and survival (Karin, 1995). Sch 52900 has recently been described as an inhibitor of a c-fos driven lac $\mathrm{Z}$ reporter gene and it was suggested that the biological target lies in the signal transduction pathway leading to the induction of a subset of immediate early genes (Chu et al., 1995). Our results show that Sch 52900 interferes with the activation of the transcription factor AP-1 by inhibiting a common target downstream of the MAP kinase MEK-1. The compound alone failed to induce an AP-1 dependent reporter gene indicating that the induction of differentiation is independent of the activation of the AP-1 transcription factor. It has recently been shown that the inhibition of the ERK pathway is required to induce apoptosis in K562 and HL-60 cells and it seems conceivable that the interference with components of the sig- 
naling pathway leading to ERK activation by Sch 52900 are responsible for the induction of apoptosis and differentiation (Kang et al., 2000). In addition, our results show that in contrast to the TPA-induced HL-60 differentiation the induction of the p 21 WAF protein by Sch 52900 is independent of the activation of the ERK kinase.

Recently evidences have been provided that small molecular inhibitors of the MEK/MAPK pathway profoundly affect the growth of acute myeloid leukemia (AML) cell lines (e.g. HL-60) and AML samples with constitutive MAPK activity whereas cell lines with a low level of constitutive MAPK activity (e.g. U937) proved relative resistant. In addition MEK inhibition sensitized leukemic cells to the proapoptotic effects of retinoids and chemotherapy (Milella et al., 2001). Our data show that the inhibition of the MAPK pathway by Sch 52900 is responsible for the growth arrest and induction of differentiation in HL-60 and U937 cells and that in contrast to the synthetic MEK inhibitor PD98059, treatment of HL-60 cells with
Sch 52900 resulted in an induction of the p $21^{\text {WAF }}$ protein.

The inhibition of the AP-1 dependent signaling pathway may also contribute to the observed immunosuppressive properties of Sch 52900 since it has been shown that the activation of the ERK cascade is required for IL-2 production and transcriptional activation of the distal NF-AT/AP-1 binding site from the IL-2 promoter in TPA/ionomycin or anti-CD3/anti-CD28 stimulated Jurkat cells (DeSilva et al., 1998).

In conclusion our data demonstrate that Sch 52900 induces differentiation and apoptosis in HL-60 cells by interfering with the signaling pathways leading to AP-1 activation downstream of MEK but the exact target remains to be elucidated.

\section{Acknowledgments}

This work was supported by a grant from the Deutsche Forschungsgemeinschaft. We thank H. Anke for providing Gliocladium strain 4-93.
Alessi D. R., Cuenda A., Cohen P., Dudley D. T. and Saltiel A. R. (1995), PD 98059 is a specific inhibitor of the activation of mitogen-activated protein kinase kinase in vitro and in vivo. J. Biol. Chem. 270, 2748927494.

Angel P. and Karin M. (1991), The role of Jun, Fos and the AP-1 complex in cell proliferation and transformation. Biochim. Biophys. Acta 1072, 129-157.

Anke H., Bergendorff O. and Sterner O. (1989), Assays of the biological activities of guaiane sesquiterpenes isolated from fruit bodies of edible Lactarius species. Food Chem. Toxic. 27, 393-397.

Chu M., Truumees I., Rothofsky M. L., Patel M. G., Gentile F., Das P. R., Puar M. S. and Lin S. L. (1995), Inhibition of $c$-fos protooncogene induction by Sch 52900 and Sch 52901, novel diketopiperazines produced by Gliocladium sp. J. Antibiotics 48, 14401445.

Collins S. J. (1987), The HL-60 promyelocytic leukemia cell line: proliferation, differentiation, and cellular oncogene expression. Blood 70, 1233-1244.

Das D., Pintucci G. and Stern A. (2000), MAPK-dependent expression of $\mathrm{p} 21^{\mathrm{WAF}}$ and $\mathrm{p} 27^{\mathrm{kip} 1}$ in PMA-induced differentiation of HL-60 cells. FEBS Lett. 472, 50-52.

DeSilva D. R., Jones E. A., Favata M. F., Jaffee B. D., Magolda R. L., Trzaskos J. M. and Scherle P. A. (1998), Inhibition of mitogen-activated protein kinase kinase blocks $\mathrm{T}$ cell proliferation but does not induce or prevent anergy. J. Immunol. 160, 4175-4181.

Domsch K., Gams H. and Anderson T.-H. (1993), Compendium of soil fungi. Vol. 1, IHW-Verlag, Eching, Germany.
Erkel G., Becker U., Anke T. and Sterner O. (1996a), Nidulal, a novel inducer of differentiation of human promyelocytic leukemia cells from Nidula candida. J. Antibiotics 49, 1189-1195.

Erkel G., Anke T. and Sterner O. (1996b), Inhibition of NF- $x$ B activation by panepoxydone. Biochem. Biophys. Res. Commun. 226, 214-221.

Flanagan W. M. and Crabtree G. R. (1992), In vitro transcription faithfully reflecting T-cell activation requirements. J. Biol. Chem. 267, 399-406.

Hozumi, M. (1998). Differentiation therapy of leukemia: achievements, limitations and future prospects. Int. J. Hematol 68, 107-129.

Jiang H., Lin J., Su Z. Z., Collart F. R., Hubermann E. and Fisher P. B. (1994), Induction of differentiation in human promyelocytic HL-60 leukemia cells activates p21, WAF1/CIP1 expression in the absence of p53. Oncogene 11, 3397-3406.

Kang C. D., Yoo S. D., Hwang B. W., Kim K. W., Kim D. W., Kim C. M., Kim S. H. and Chung B. S. (2000), The inhibition of ERK/MAPK not the activation of $\mathrm{JNK} / \mathrm{SAPK}$ is primarily required to induce apoptosis in chronic myelogenous leukemic K562 cells. Leuk. Res. 24, 527-534.

Karin M. (1995), The regulation of AP-1 activity by mitogen-activated protein kinases. J. Biol. Chem. 270, 16483-16486.

Kinloch R. A., Treherne J. M., Furness L. M. and Hajimohamadreza I. (1999), The pharmacology of apoptosis. Trends in Pharmaceutical Science 20, 35-41.

Kroll M., Arenzana-Seisdedos F., Bachelerie F., Thomas D., Friguet B. and Conconi M. (1999), The secondary 
fungal metabolite gliotoxin targets the proteolytic activities of the proteasome. Chem. Biol. 6, 689-698.

Lin R., Egan D. A. and Evans R. M. (1999), Molecular genetics of acute promyelocytic leukemia. TIG 15, $179-184$

Matilla P.S., Ullman K. S., Fiering S., Emmel E. A., McCutcheon M., Crabtree G. R. and Herzenberg L. A. (1990), The actions of cyclosporin A and FK506 suggest a novel step in the activation of $\mathrm{T}$ lymphocytes. EMBO J. 9, 4425-4433.

McGahon A. J., Seamus J. M., Bissonette R. P., Mahboubi A., Shi Y., Mogil R. J., Nishioka W. K. and Green D. R. (1995), The end of the (cell) line: Methods for the study of apoptosis in vitro. Methods Cell Biol 46, 153-185.

Meighan-Mantha R. L., Wellstein A. and Riegel A. T. (1997), Differential regulation of extracellular signalregulated kinase 1 and 2 activity during 12-O-tetradecanoylphorbol-13-acetate-induced differentiation of HL-60 cells. Exp. Cell Res. 234, 321-328.

Milella M., Kornblau S. M., Estrov Z., Carter B. Z., Lapillonne H., Harris D., Konopleva M., Zhao S., Estey E. and Andreeff M. (2001), Therapeutic targeting of the MEK/MAK signal transduction module in acute myeloid leukaemia. J. Clin. Invest. 108, 851-859.

Nagy L., Thomazy V. A., Shipley G. L., Fesus L., Lamph W., Heyman R. A., Chandraratna R. A S. and Davies P. J. A. (1995), Activation of retinoid X receptors induces apoptosis in HL-60 cell lines. Mol. Cell. Biol. 15, 3540-3551.

Pahl H. L. and Baeuerle P. A. (1995), A novel signal transduction pathway from the endoplasmatic reticulum to the nucleus is mediated by transcription factor NF- $x$ B. EMBO J. 14, 2580-2588.
Pahl H. L., Krauss B., Schulze-Osthoff K., Decker T., Traenckner E. B., Vogt M., Myers C., Parks T., Warring P., Muhlbacher A., Czernilofsky A.P. and Baeuerle P. A. (1996), The immunosuppressive fungal metabolite gliotoxin specifically inhibits transcription factor NF-xB. J. Exp. Med. 183, 1829-1840.

Rooney J. W., Sun Y. L., Glimcher L. H. and Hoey T. (1995), Novel NFAT sites that mediate activation of the interleukin-2 promoter in response to T-cell receptor stimulation. Mol. Cell. Biol. 15, 6299-6310.

Scott R. E. (1997), Differentiation, differentiation/gene therapy and cancer. Pharmacol. Ther. 73, 51-65.

Shu Y.-Z. (1998), Recent natural products based drug development: a pharmaceutical industry perspective. J. Nat. Prod. 61, 1053-1071.

Thompson C. B. (1995), Apoptosis in the pathogenesis and treatment of disease. Science 267, 1456-1462.

Wang X. and Studzinski G. P. (2001), Inhibition of p38 MAP kinase potentiates the JNK/SAPK pathway and AP-1 activity in monocytic but not in macrophage or granulocytic differentiation of HL-60 cells. J. Cell. Biochem. 82, 68-77.

Warrell R. P., De Thé H, Wang Z.-Y. and Degos L. (1993), Acute promyelocytic leukemia. New Eng. J. Med 329, 177-189.

Zhang W., Grasso L., McClain C. D., Gambel A. M., Cha Y., Travali S., Deisseroth A. B. and Mercer W. E. (1995), p53-independent induction of WAF1/CIP1 in human leukaemia cells is correlated with growth arrest accompanying monocyte/macrophage differentiation. Cancer Res. 55, 668-674. 
Nachdruck - auch auszugsweise - nur mit schriftlicher Genehmigung des Verlages gestattet Satz und Druck: AZ Druck und Datentechnik GmbH, Kempten 